\title{
Afordancje obiektów instytucji kultury. Badanie wizualnej oferty muzeum organizacji z perspektywy strategii komunikacyjnej
}

\author{
Abstract \\ The Affordances of Cultural Institutions' Objects: The Evaluation \\ of Organizational Museum Visual Offer from the Perspective \\ of Communication Strategy
}

The interdisciplinary study bordering communication management and media psychology aims to present the possibility of using the "affordance" concept in the cultural institutions study, and more precisely in the organization's museum research. It may be particularly useful to extend the theoretical apparatus to describe the phenomena of the organizational iconosphere, where behavioural models seem to be insufficient to analyse the relationship between the designed institutional environment and its ability to influence the visiting audience. The author has conducted qualitative research on visual messages in the newly created Polish Vodka Museum in Warsaw. The theoretical foundation was the model proposed by Meyer et al. [2018], which synthesizes the functions of visual messages in the organization's space. The article, referring to the theory of affordances, presents a new application of this concept in the analysis of the communication potential of an organization's museum. The assessment of the offer of cultural institutions may begin with the analysis of affordances of the main objects exhibited. This is a complementary approach to studying the preferences and experiences of visitors.

Keywords: organizational museum, visual communication, affordances, qualitative research, visual perception

Słowa kluczowe: muzeum organizacji, komunikacja wizualna, afordancje, badania jakościowe, percepcja wizualna 


\section{Wprowadzenie}

Termin instytucja kultury obejmuje szerokie spektrum znaczeń oraz różnorodny status formalnoprawny. Najczęściej są to miejsca, gdzie dominuje konkretna forma działalności kulturalnej, a zwłaszcza prezentacja wystaw, spektakli, koncertów [Bańdo et al. 2019], choć nie tylko [por. Szulborska-Łukaszewicz 2012]. To „wielozadaniowe centra", heterogeniczne miejsca zaspokajające potrzeby kulturowe zróżnicowanych grup odbiorców [Datko, Necel 2011: 4]. Świadome działanie w celu kształtowania, tworzenia, organizowania warunków do uprawiania działalności kulturalnej ma formę publiczną, ale z punktu widzenia charakterystyki założyciela, możemy ją podzielić na państwową i prywatną. Raport Ministerstwa Kultury i Dziedzictwa Narodowego z 2007 roku [Raport MKiDN 2007] głosi, że obszar kultury jest zdominowany przez podmioty państwowe, zaś liczba podmiotów prywatnych podejmujących działalność kulturalną rośnie, ale nadal stanowi margines. Po dziesięciu latach od wydania ww raportu, dane GUS za 2017 wskazują, że w sektorze samych muzeów, liczba instytucji prywatnych dalej wzrasta [Raport GUS 2017]. W 2017 w Polsce działalność prowadziło 949 muzeów i oddziałów muzealnych, ośrodki te odwiedziło w sumie 37,5 mln osób. Najwięcej muzeów należało do sektora publicznego (79,3\%), w tym dla większości organizatorem były jednostki samorządu terytorialnego. W sektorze prywatnym najwięcej muzeów organizowanych było przez osoby fizyczne (37,8\%). Obecnie jesteśmy więc świadkami ciągłej modyfikacji struktur organizacyjnych instytucji kultury. Wprowadzenie do ich zarządzania metod zintegrowanej komunikacji marketingowej jest wymogiem współczesnej ekonomii, w której konkurencyjność i efektywność dotyka także sfer niematerialnych, symbolicznych funkcjonowania człowieka. Na te ostatnie można wpływać przez zarządzanie komunikacją, czyli „koordynację komunikacji wewnętrznej i zewnętrznej, aby stworzyć i podtrzymywać korzystną reputację organizacji wśród tych grup interesariuszy, od których jest ona zależna" [Corenlissen 2012: 26].

Niniejsze opracowanie będzie dotyczyć muzeum stworzonego właśnie w sektorze prywatnym, reprezentowanego przez fundację, założoną w celach edukacyjnych, ale także promocyjnych [por. Sprawozdanie Fundacji Polska Wódka 2018]. Taki hybrydalny model instytucji stanowi ciekawy przykład mieszania granic pomiędzy tym, co publiczne i prywatne, biznesowe i „trzeciosektorowe”. Muzeum Polskiej Wódki jest przykładem podmiotu stworzonego zarówno przez mechanizmy rynkowe, jak i kulturotwórcze1. O ile bowiem termin „ekonomika kultury” [Dragićević-Šešić, Stojković 2010] często odnosi się do wpływu, jaki orientacja marketingowa

${ }^{1}$ Muzeum Polskiej Wódki jest muzeum organizacji, założonym przez Fundację „Polska Wódka”, którą wspiera francuski koncern Pernod Ricard właściciel m.in. marek Absolut, Becherovka, Luksusowa i Wyborowa. Mieści się w Centrum Praskim „Koneser” w odrestaurowanej przestrzeni dawnej Warszawskiej Wytwórni Wódek „Koneser” z końca XIX wieku. 
przedsiębiorstw ma na instytucje kultury, o tyle współcześnie może świadczyć także o relacji odwrotnej. Marketingowo zorientowany podmiot zachowuje się aktywnie wobec rynku, dostosowuje się do niego, stymuluje popyt. Galeria, muzeum, teatr podejmują działania marketingowe mające na celu zwiększenie zainteresowania swoją ofertą wśród publiczności. Istnieje jednakże druga strona tego samego procesu, a mianowicie podmioty rynkowe, przedsiębiorstwa nastawione komercyjnie, mogą wykorzystywać przestrzeń kultury w celu zwiększania zainteresowania swoimi produktami i usługami. Weronika Pokojska [2014: 117-118] stawia nawet tezę, że mają one szansę być „muzeum idealnym”. Autorka opisuje Mercedes-Benz Museum w Stuttgarcie jako „pasjonującą" i „uniwersalną” przestrzeń kultury motoryzacyjnej wywodzącej się z Niemiec, kolebki motoryzacji, ale realizującej cele promocyjne dla jednej marki - Mercedes-Benz. Rozwijającym się trendem w sektorze biznesowym jest zakładanie własnych instytucji kultury², a zwłaszcza muzeów. We Włoszech liczne są muzea marek odzieżowych [por. Carù, Ostillio, Leone 2017; Iannone, Izzo 2017], wizyta w Holandii zaś nie jest pełna bez odwiedzin Amsterdamu wraz z „doświadczeniem marki Heineken” [por. Smit 2014]. W Polsce Monika Kaczmarek-Śliwińska [2015: 125] podaje, że pierwsze muzea marki pojawiły się około 2000 roku i dotyczyły marek regionów. Warto we wprowadzeniu zwrócić uwagę na niejednoznaczność słownika terminologicznego opisującego niepubliczne instytucje wystawiennicze, które prezentują dorobek i misję przedsiębiorstwa. Można bowiem mówić o muzeum marki, muzeum korporacyjnym, muzeum firmowym oraz muzeum organizacji. Ten ostatni termin wydaje się najszerszy i został wybrany dla niniejszego opracowania. Kaczmarek-Śliwińska [2015: 126] cytuje opracowanie Arnolda Pabiana i Aleksandra Pabiana [2009], wskazując, czym od publicznego różni się muzeum założone przez firmę. To ostatnie promuje przede wszystkim usługi lub produkty tylko jednego przedsiębiorstwa i finansowane jest $\mathrm{z}$ jego środków. Najczęściej budowane jest z rozmachem architektonicznym i wykorzystuje najnowsze osiągnięcia techniki i multimediów w celu wywarcia jak największego wrażenia na odbiorcach. Muzea organizacji mają także za zadanie komunikowanie rynkowi takich wartości jak doświadczenie, zaufanie i innowacyjność. Warto rozszerzyć opisywany przez autorów katalog celów i dodać, że współcześnie takie muzea mają przede wszystkim cele wizerunkowe i mogą być zaliczane do technik realizacji strategii komunikacyjnych, zwłaszcza w ramach public relations organizacji. Odwiedzający stają się odbiorcami licznych komunikatów informacyjnych i perswazyjnych, gdyż zanurzając się w świat nadawcy instytucjonalnego, potęgują

${ }^{2}$ Na przykład właściciel globalnej agencji reklamowej Saatchi and Saatchi ma swoją prywatną galerię, która stała się marką samą w sobie w świecie kultury, a mianowicie Saatchi Gallery. Instytucja przedstawia się obecnie jako jedna z czołowych galerii sztuk wizualnych w świecie mediów społecznościowych, z ponad $2 \mathrm{mln}$ "lajków” na profilu. Por. https://www.saatchigallery.com/ [odczyt: 23.04.2019]. Być może jesteśmy świadkami procesu, w którym galeria przyćmiła renomę podmiotu rynkowego, który ją założył. 
doświadczenie i intensyfikują bycie z nim w relacji. Jedną z najnowszych prób zainicjowania takiej formy komunikacji jest Muzeum Polskiej Wódki (MPW), otwarte w czerwcu 2018 roku w Warszawie.

Celem tego opracowania będzie wskazanie nowego pola analiz instytucji kultury, a dokładnie zostanie pogłębiona refleksja nad jej sferą wizualną. Wyróżniając obszar badawczy w postaci muzeum organizacji, wytypowana zostanie płaszczyzna analizy afordancji przekazów wizualnych w przestrzeni wystawienniczej instytucji kultury. Pola analiz obrazuje rysunek 1.

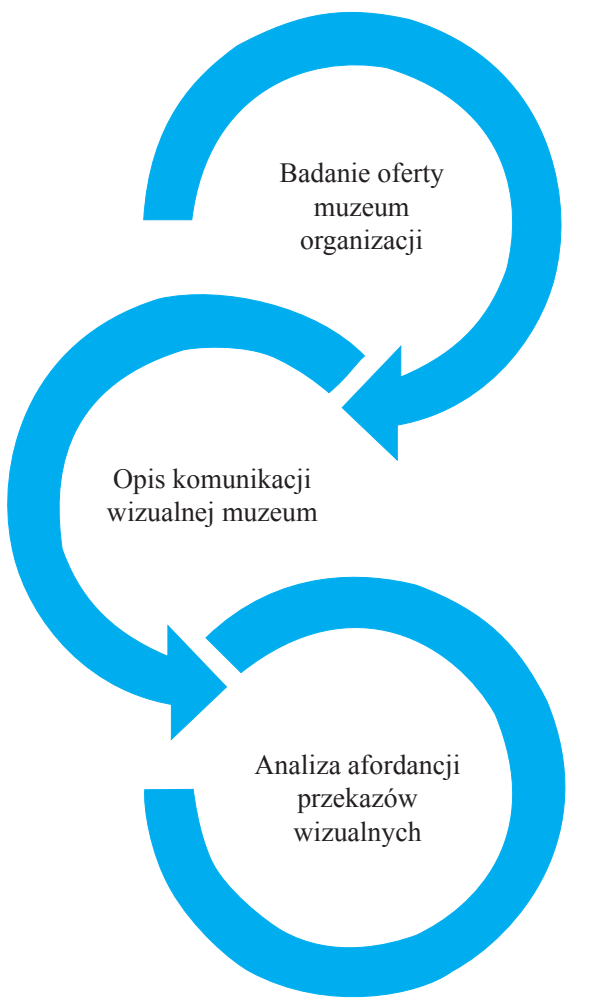

Rysunek 1. Pola badawcze instytucji kultury z perspektywy nadawcy komunikatów Źródło: opracowanie własne.

Sformułowane uogólnienia i syntezy są próbą rekonstrukcji społecznej rzeczywistości organizacji i wpisują się w tak zwany paradygmat interpretatywny, stanowiąc realizacje metodologii refleksyjnej [Czarniawska 2013]. Zastosowano metody: obserwacji uczestniczącej, wywiadów pogłębionych oraz analizy zawartości oficjalnych dokumentów MPW w sierpniu 2018 roku. Klucz kategoryzacyjny dla uzyskanych danych stanowiły cztery funkcje afordancji z modelu Renate Meyer i współautorów 
[2018], omówione w dalszej części opracowania. W artykule jako perspektywę wskazano z jednej strony zakorzenienie odwiedzających w świecie zmysłów, dokładnie wzrokocentryzm doświadczania muzeum, $\mathrm{z}$ drugiej zaś intencjonalne konstruowanie przekazów wizualnych przez komercyjnego nadawcę instytucjonalnego, który owo wizualne doświadczenie publiczności chce wykorzystać w celach strategicznych PR. $\mathrm{W}$ instytucji kultury badane są przykłady komunikacji wizualnej według funkcji afordancji obiektów muzeum. Konrad Chmielecki [2018] podkreśla, że „widzenie przez kulturę" wymaga interdyscyplinarnego podejścia. Nicholas Mirzoeff [2016: 3] pisze zaś o „zdarzeniu wizualnym”, które współcześnie lepiej niż słowo „obraz” opisuje centralny aspekt procesu odbioru wizualnych technologii medialnych w procesie komunikowania społecznego. W artykule najpierw opisano wizytę w MPW, następnie przedstawiono analizę afordancji wraz z przykładami z omawianej instytucji kultury. Opis czterech funkcji afordancji służy zobrazowaniu tego, jak działa system definiowania wizualnego świata muzeum.

\section{Wizyta w Muzeum Polskiej Wódki}

$\mathrm{Na}$ tle sukcesu dotychczasowych centrów browarniczych, między innymi Lecha i Żywca, można mówić o pewnym trendzie komunikacyjnym w sektorze alkoholi. Picie ma być formą nie tylko rozrywkowego spędzania czasu, a raczej elementem kultury czasu wolnego dawniej i dziś. Ponadto niekoniecznie musi kojarzyć się jedynie z negatywnymi konsekwencjami dla pijącego. Strategia komunikacji muzeum i towarzyszące jej działania PR, zmierzają do przejścia od niesformalizowanych sposobów działania społecznego do uregulowanych i względnie stałych form aktywności związanych z piciem wódki. Zwiększona instytucjonalizacja, której ma sprzyjać działalność public relations muzeum (zarówno wewnętrzna, jak i zewnętrzna), sankcjonuje aktywności społeczne, kreuje pozytywne wartościowanie zakupu oraz spożycia polskiej wódki. Tym samym przekłada się na poszerzenie pola znaczeniowego portfolio marek, zwłaszcza tych należących do koncernu wspierającego Muzeum Polskiej Wódki. Barbara Kożuch [2007: 88], opisując uniwersalne cechy organizacji, wymienia między innymi jej celowe zorientowanie oraz zdolność do utrwalania wzorców zachowań. Taki cel komunikacyjny wymaga rozbudowanych i kompleksowych instrumentów do jego realizacji. Realizować go można poprzez multimodalne kanały komunikacji muzeum, z naciskiem na kanał wizualny.

Wywiady - zarówno z menedżerem do spraw komunikacji i promocji, jak i z przewodnikiem w muzeum - miały odpowiedzieć na pytanie o główne cele komunikacji instytucjonalnej, a także środki wykorzystywane do ich realizacji w ramach ikonosfery. Jak pisał John Berger, „obraz to widok, który został odtworzony lub zreprodukowany. Obraz to wygląd rzeczy lub zbiór wyglądów, wyrwany z pierwotnego kontekstu, w którym powstał i utrwalony na kilka chwil lub kilka stuleci. Każdy obraz 
ucieleśnia jakiś sposób widzenia" [Berger 2008: 7]. Obiekty recypowane wizualnie, zwłaszcza design budynku muzeum, jego lokalizacja oraz ekspozycja wskazują na chęć pokazania wódki jako alkoholu tradycyjnie polskiego. Wywiady i obserwacja uczestnicząca, przeprowadzone w sierpniu 2018 roku, niecałe dwa miesiące od oficjalnego otwarcia placówki, miały za zadanie zweryfikować tę hipotezę. Według pracowników MPW celem istotnie jest odbrązowienie kultury picia, oderwanie jej od negatywnych konotacji czasów PRL, kognitywna nobilitacja trunku, a także w sferze emocjonalnej wywołanie dumy z polskości i tradycji wódki znad Wisły. Podstawowym dążeniem MPW, podkreślanym najczęściej przez rozmówców, jest edukacja i „walka z hipokryzją" publicznego dyskursu dotyczącego wódki. Zdaniem przedstawicieli instytucji blokuje on rozwój kulturalnego picia. Modelem aspiracyjnym muzeum jest, w sferze znaczeń przypisywanych polskiej wódce, móc dorównać statusowi francuskiego koniaku i irlandzkiej whisky. Mówiąc językiem marketingu, chodzi o zmianę kategorii produktu na bardziej prestiżowy [por. Szwajca 2009]. Główne przeszkody to historyczne zaszłości, a mianowicie czasy wojenne i komunistyczne, kiedy to wódka była traktowana jako waluta, dzięki której można było wszystko załatwić. Dodatkową barierą dla komunikacji jest ustawa o wychowaniu w trzeźwości zakazująca promocji wysokoprocentowych alkoholi w mediach masowych oraz namawiania do picia. „Szerzymy wiedzę o polskiej wódce” - to hasło przewodnie działań muzeum. I rzeczywiście zarówno na stronie internetowej, w materiałach promocyjnych, jak i w wywiadach odwołania do edukacji i wiedzy pojawiają się najczęściej. Słowo „wiedza” jest w zasadzie zawsze obecne w materiałach prasowych dystrybuowanych w mediach, eksponowane na bilbordach i innych nośnikach reklamowych. Mamy więc do czynienia ze zintegrowaną strategią komunikacyjną, co zadeklarował menedżer do spraw komunikacji i promocji.

Samo muzeum można zwiedzać tylko z przewodnikiem, który pełni funkcję mentora $\mathrm{w}$ doświadczaniu oferty instytucji. Są to osoby gruntownie przeszkolone w celach komunikacyjnych muzeum, absolwenci między innymi historii sztuki, socjologii, antropologii, którzy muszą zdawać egzaminy w MPW z wiedzy o polskiej wódce właśnie. Zwiedzanie muzeum ma charakter mało spontaniczny, raczej zaplanowany, kiedy etapami (piętrami/salami) realizuje się dedykowany program dydaktycznej opowieści o polskości i historii wódki. Naprzeciwko wejścia, gdzie dominuje beton, szkło, widać kontuar z biletami i informacjami, a za nim ścianę wody, która ma przywodzić na myśl przezroczystą wódkę. Wizyta zawsze zaczyna się od seansu filmowego. W starannie zaprojektowanym kinie można usiąść w brązowych, aksamitnych fotelach $\mathrm{z}$ warszawskiego Teatru Komedia, w otoczeniu miedzianych ścian kameralnej przestrzeni sali. Widz ogląda przemyślany dokument o wódce czasów PRL, ale w kontekście designu opakowań i działań promocyjnych w tamtych niełatwych czasach. Zdjęcia do filmu kręcono w fabryce Koneser. To silny perswazyjnie materiał pokazujący PRL w stylu vintage, zabarwiony humorem niczym z filmów Barei, pokazujących wódkę od strony jej twórców (wypowiada się 
m.in. projektant etykiet Wyborowej i kierowniczka działu handlu zagranicznego producenta), nie zaś odbiorców (pijących czy handlujących nią). Przewodnik zapytany o reakcje emocjonalne publiczności na seans wymienia głównie rozczulenie, sentyment, fascynację, niedowierzanie i zaciekawienie. Rezultatem oglądania filmu jest także wzmożona uważność widzów, przykucie uwagi i inicjacja interakcji z prowadzącym wycieczkę. Potem bowiem następuje przejście do kolejnej sali, gdzie od czasów antyku rozpoczyna się wizualna opowieść o początkach wódki na ziemiach polskich. Płynne przejście w średniowiecze, w czym pomaga mapa i wizualizacje informacji z wybranymi datami „historii wódki”. Pojawiają się terminy „inkunabuł”, „alembik”, „okowita” itp. - zawsze zwizualizowane. W kolorach dominuje ciemny brąz, przytłumione światło żółte, w materiałach drewno i kamień charakterystyczne dla dawnych epok. Ekrany multimedialne pokazują stare księgi, które można przeglądać wirtualną lupą, odszyfrowywać średniowieczną w stylu typografię, zagłębiać się w receptury apteczne „aqua vitae” (etymologia dla słowa „okowita”), a także studiować transkrypcje starodruków z Biblioteki Narodowej. Nowoczesne technologie prezentują dawne czasy. Można doświadczyć obrazów historii. W kolejnej części sali, po przejściu obok turbin ze składnikami wódki (np. zwiedzający ma możliwość oglądać i dotykać zimne ziemniaki), prezentowana jest już działalność w wiekach XVII i XVIII na ziemiach polskich. Za pomocą reprodukcji malarskich podkreślających przeszłość reprezentacji wizualnych prezentowane są obrazy dworu szlacheckiego, żydowskiej karczmy. Otwierane drewniane okiennice kryją cytaty i rysunki z pamiętników, wielkie mapy na drewnianej ścianie inkrustowane $\mathrm{w}$ dawne wzory i wypalone nadruki potęgują wrażenie zanurzenia w czasach minionych. Na dębowym trzymetrowym stole prezentowana jest wizualna opowieść o wojnach i ówczesnych królach, wpisując się w historyczną narrację sławiącą okres „Polski od morza do morza”. W kolejnej sali, której podłogę zdobią deski z beczek po nalewkach owocowych, świat wódki prezentowany jest od strony historii technologii wytwarzania. Potem odwiedzający płynnie przechodzi do XIX wieku, ogląda aparat Pistoriusa z 1817 roku do destylowania alkoholu (pozwalał na ciągły obieg produkcji spirytusu), a także tak zwany parnik do odparowywania alkoholi, zdjęcia fabryki. W tej części pojawia się też omówienie neogotyku siedziby Konesera oraz piktogramy z odwołaniami do tradycji żydowskich producentów wódki (hebrajskie litery i symbole judaistyczne). Widać kadzie, wirtualny ogień, w otoczeniu znów dominuje beton i cegła, tak charakterystyczne dla budynku muzeum, a także praskiej części Warszawy. Ostatnim etapem na tym piętrze jest ekspozycja butelek w transparentnych i lustrzanych regałach, drewno z wcześniejszych sal zastępuje tu stal i szkło. Ekspozycja w tej części nie przytłacza, jest niczym światło po wiekach dawnych, relaksuje odbiorcę. Można obejrzeć na ekranach filmiki z czasów PRL, oglądać butelki z tamtych lat (niektóre pełne), etykiety, reklamy. Lata siedemdziesiąte i osiemdziesiąte minionego wieku pokazane są przez nawiązania do ówczesnej muzyki, sztuki, odniesienia między innymi do grupy Rolling Stones. Następnie 
chronologiczny przeskok i rok 2004, sygnalizowany przez filmik z wejścia Polski do Unii Europejskiej w kontekście dostępu do wódki w stylu premium. Współczesność to obrazy picia koktajli na pokazach mody, festiwalach, barmańskie show (m.in. ambasadora polskiej wódki Macieja Starosolskiego). Można obejrzeć butelki wódki projektowane przez słynnych architektów, na przykład Franka Gehry’ego. Ostatnie piętro jest już przestrzenią doświadczeń indywidualnych, można włożyć interaktywne gogle i zobaczyć, jak zmienia się wizja po wypiciu kolejnych promili alkoholu. Liczne interaktywne projekcje na ścianach nawiązują do doświadczeń fizykalnych picia wódki. Po wyjściu z sali ostatnim etapem jest - oddzielony korytarzem, dla chętnych i za dodatkową opłatą - tak zwany tasting. Odbywa się on w przestronnym barze pod nazwą „Akademia Polskiej Wódki”, gdzie dominuje szkło, uwagę przykuwają wzory złotych kłosów i łanów zbóż, widać starannie zaprojektowane metalowe złote okucia modernistycznych mebli. Można spróbować przynajmniej kilku typów wódki. Eleganckie, wysokie szklane kieliszki, stoją na podstawce w trzech kolorach podstawowych: czerwonym, niebieskim i żółtym. Tłem zawsze jest biel. Te kolory dominują w materiałach wizualnych muzeum. W barze jasnym i przestrzennym wzrok odpoczywa, gdyż to smak ma być angażowanym zmysłem. Przewodnik podkreślał, że wielu zwiedzających z zachwytem i zaskoczeniem odkrywa, że wódka smak ma. Wizyta w barze trwa około 15 minut. Całe zaś oprowadzanie do około dwóch godzin. Moim rozmówcom wydaje się, że zanurzeni w świat muzeum wychodzą dużo bardziej przekonani o jej tradycyjnym charakterze, z wiedzą o jej historii i polskości.

\section{Analiza oferty muzeum w perspektywie teorii afordancji}

Zadając sobie pytanie, dlaczego muzeum jest przestrzenią tak bardzo perswazyjną w kreowaniu doświadczeń, w tym opracowaniu proponuję zastosowanie integrującego modelu Meyer i współpracowników [2018], aby wyjaśnić fenomen wizualnego doświadczenia wizyty w MPW. Tym samym studium przypadku zostanie przeprowadzone $\mathrm{z}$ użyciem modelu teoretycznego o ponadjednostkowym charakterze. Odwołując się do typologii przypadków Marty Strumińskiej-Kutry i Izabeli Koładkiewicz [2012: 13-14] z podręcznika badań jakościowych pod redakcją D. Jemielniaka, można stwierdzić, że jest to eksplanacyjne studium przypadku (explanatory case study), gdyż koncentruje się na analizie przyczyn i efektów występujących relacji. Muzeum Polskiej Wódki jest nowo otwartą organizacją o jasno deklarowanych celach komunikacyjnych, ale o ofercie silnie wartościującej przekaz i bogatej w odniesienia symboliczne. Częste nawiązania do przeszłości i liczniejsze jej wizualne reprezentacje niż teraźniejszości i przyszłości produktu mogą sprzyjać nobilitacji wysokoprocentowego alkoholu, a nawet służyć sytuowaniu go w obszarze dziedzictwa kulturowego kraju. Wódka w muzeum jest produktem wpisywanym w sferę praktyk kulturowych narodu, instytucja stara się to pokazać jak najbardziej 
pozytywnie oraz uszlachetnić i wywołać u odbiorcy emocje pozytywne o genezie refleksyjnej $^{3}$ [por. Imbir, Jarymowicz 2011]. Wywiady z przedstawicielami muzeum wskazały na wywołanie u odwiedzających dumy z „polskości i tradycji wódki”, jako na jeden z podstawowych celów muzeum. Aby zawęzić pole analiz oferty muzeum, w niniejszym opracowaniu studium przypadku będzie się odnosić do teorii komunikacji wizualnej stosowanej w organizacji. Zbieranie i opracowanie danych kategorialnych odbywało się według modelu Meyer i współautorzy [2018], dane wizualne podlegały raczej klasyfikacji, nie kwantyfikacji. Jolanta Maćkiewicz [2017: 40] z jednej strony podkreśla konieczność integracji modalności zmysłowych w badaniach, z drugiej - zwraca uwagę, że intertekstualność dzisiejszych mediów, a muzeum jest z pewnością przestrzenią przepełnioną mediami, jest skomplikowana i wymaga wydzielania „modusów zmysłowych”. Oczywiście teksty werbalne jako materiał badawczy, a teoria narracji jako podłoże teoretyczne, mogą być komplementarne dla zaproponowanego modelu, jednak ze względu na objętość danych empirycznych przekracza to możliwości i cel tego artykułu.

Działania instytucji kultury zaprzęgają świat zmysłów publiczności w maszynę wyrafinowanego wpływu społecznego, służącego partykularnym interesom instytucji, dokładnie fundatora muzeum. Skoro ponad $70 \%$ informacji dociera do mózgu za pomocą zmysłu wzroku [Newton 2004], można przyjąć założenie, że ocena oferty instytucji kultury najczęściej jest konsekwencją patrzenia ${ }^{4}$. Odbiór, przenoszenie i przetwarzanie informacji porządku ukrytego rozpoczyna percepcja wzrokowa i jak fundamentalnie reasumuje Jan Młodkowski [1998: 9], widzenie jest „potocznym kryterium istnienia świata zewnętrznego”. Jeśli wziąć pod uwagę cel komunikacyjny komercyjnej instytucji kultury, jaką jest MPW, adresując komunikaty do zmysłu wzroku, można skutecznie pozawerbalnie demonstrować ideały i misje organizacji. W ramach szeroko pojętej kultury wizualnej, czyli procesów komunikacji wizualnej zachodzących w danym społeczeństwie, muzeum wpisuje praktyki

${ }^{3}$ Według teorii regulacyjnej można podzielić emocje nie tylko ze względu na walencję (pozytywne $v s$. negatywne stany pobudzenia), ale także na dwa typy: automatyczne i refleksyjne. Emocje automatyczne są hedonistyczne i homeostatyczne, wytrącają organizm z równowagi, jak np. radość lub wstręt. Drugi typ emocji to pobudzenie o typie refleksyjnym, związane ze standardami Ja oraz aksjologią, takie jak np. hańba oraz duma. Odwołania do struktur poznawczych odbiorcy, wartościowanie wydarzeń historycznych w kontekście produktu „wódka polska”, wskazuje na cel wzbudzenia emocji refleksyjnych. Skutkuje to nie doświadczeniem incydentalnym, szybkim wzbudzeniem uczucia radości odwiedzającego, ale raczej doświadczeniem silnie absorbującym. Takie doświadczenie w teorii marketingu doświadczeń (i wg typologii Shawa [2005]) jest niezapomniane, angażujące i urzekające.

${ }^{4} \mathrm{~W}$ tym miejscu warto podkreślić, że muzeum mogą odwiedzać także osoby z niepełnosprawnościami, w tym niewidome. Nie jest celem artykułu w jakikolwiek sposób wykluczenie tych odwiedzających, a jedynie zwrócenie uwagi na dominację widzów patrzących wśród publiczności muzeum. Co więcej, istnieją wystawy projektowane nawet z całkowitym wyłączeniem zmysłu wzroku (por. https://niewidzialna.pl/ [odczyt: 18.04.2019]). Opisanie doświadczenia wizyty osób niewidzących przekracza założenia tego artykułu. Pogłębienie tej tematyki można znaleźć w artykule Paplińskiej [2008]. 
korzystne instytucjonalnie w doświadczenie publiczności muzeum. Odbiorowi wzrokowemu bodźców z otaczającego świata towarzyszy przekonanie patrzącego o autentyczności obrazów i obiektywności recepcji. Podsumować je może zdanie: Ja byłem, ja widziałem, ja wiem. Subiektywna generatywność recepcji wzrokowej to silny argument na rzecz skuteczności komunikacji wizualnej. Adam Dzidowski podkreśla, że takie praktyki można badać, a dokładnie - analizować „wizualne manifestacje funkcji, struktury i strategii organizacji, które wpływają na jej kulturę oraz kondycję jednostek i grup społecznych wchodzących w jej skład” [Dzidowski 2011: 54]. Artefaktami wizualnymi można zarządzać w przestrzeni muzeum, wpływać na splot wszechstronnych interakcji odwiedzających, na ich interpretację obiektów ekspozycji, usytuowania budynku itp. Jak działa ów system definiowania wizualnego w muzeum? Jak analizować narzędzia służące do realizacji opisanych funkcji? Pomocna może w tym być teoria afordancji (affordances theory), wywodząca się z prac psychologa percepcji Jamesa J. Gibsona, powstała w latach sześćdziesiątych XX wieku. Jak tłumaczy Andrzej Klawiter [2012], „afordancja” jest terminem, który pomaga łączyć odbieranie świata za pomocą zmysłów z działaniem. Afordancje według badacza to tak zwane oferty. Opisują, co odbiorca może uczynić z przekazem. Z punktu widzenia komunikacji wizualnej afordancje są sposobnościami działania i oddziaływania przekazów wizualnych na odwiedzających muzeum, związane z ich cechami i zdolnościami percepcyjnymi. Percepcja wizualna rozumiana jest tu jako aktywne szukanie ustrukturowanej informacji, mogącej usprawnić działanie człowieka w otoczeniu organizacji. Przyjmijmy więc, że afordancje wizualne w swej treści niosą piktorialne informacje o tym, jaki użytek może zrobić perceptor, czyli gość instytucji kultury, z przedmiotu, który je wysłał, na przykład eksponatu w przestrzeni organizacji. Afordancje nie są bodźcami, nie są sprawczymi przyczynami, a jedynie wynikającymi z percepcji możliwościami wykorzystania bodźców, także wizualnych. Stanowią alternatywę dla diagnozy zjawiska perswazji, badania bezpośrednich skutków działania komunikatów na odbiorców. Tak rozumiane afordancje mogą stanowić element analizy potencjału kodu piktorialnego w ramach strategii komunikacyjnej organizacji.

Na teorii afordancji opiera się model Meyer i współpracowników [2018], gdzie zestawiono funkcje kodów werbalnych i wizualnych mających zwiększać instytucjonalizację praktyk organizacyjnych. Autorzy, interdyscyplinarny zespół z Danii, Australii i Francji, prezentują koncepcję, która w zawężeniu do kodów ikonicznych, stanowiła teoretyczną podbudowę (dostarczała kategorii do opisu czterech funkcji) do analizy oferty wizualnej muzeum wysokoprocentowego alkoholu na warszawskiej Pradze. Meyer i współpracownicy zestawiają trzy źródła wyjątkowej charakterystyki komunikatów wizualnych: semiotyczny, kognitywny i kulturowy. W wymiarze semiotycznym możemy analizować obrazy z wykorzystaniem klasycznej teorii znaków wywodzącej się z Charles'a Peirce’a i Ferdinanda de Saussure’a [por. Rose 2010; Hudzik 2017], dokonywać typologizacji w kategoriach ikoniczności czy symboliczności, 
analizować struktury informacji i na przykład perspektywę w obrazach prezentowanych w muzeum. Kolejna jest charakterystyka kognitywna przekazów wizualnych, a mianowicie obszar, w którym opisujemy procesy percepcyjne determinowane przez obraz, zwłaszcza podkreśla się poznawczą holistyczność i natychmiastowość odbioru wizualnego (w przeciwieństwie do przekazu werbalnego, który jest linearny i sekwencyjny). I trzecie źródło cech przekazów piktorialnych - to kulturowe przekonania im towarzyszące. Gunther Kress i Theo van Leuveen [2006] już przed Meyer z zespołem wykazali, że społeczne, ideologiczne przekonania dotyczące statusu obrazów są warunkowane przez wspólnoty je wytwarzające i recypujące. Obrazom w kulturach zachodnich towarzyszy swoista swoboda i większa indywidualizacja interpretacji niż tekstów. Meyer i współautorzy [2018: 395] określają ową charakterystykę mianem słabszych uregulowań społecznych dla obrazów (weak regulation and accountability). Poza kanonem znanym historykom sztuki przeciętny odbiorca wizualnych przekazów ma poczucie dowolności w ich ocenie w przestrzeni publicznej oraz w mediach. Z kolei niegramatyczne zdanie, nielogiczna wypowiedź tekstowa jest wychwytywana od razu, nawet przez niewprawne ucho. Relacja znaków w obrazie, specyfika kognitywnej ich recepcji wraz z towarzyszącą normą praktyk kulturowych stanowią trzy źródła specyfiki wizualnych przekazów. Semiotyczne, kognitywne i kulturowe charakterystyki tworzą dla komunikatów wizualnych swoistą „infrastrukturę" [Meyer et al. 2018: 396] i są podbudową dla afordancji, czyli możliwości odbioru oferty muzeum recypowanej wizualnie. Infiltracja, lokowanie poprzez kompozycję, przykucie uwagi oraz materializacja składają się na piktorialne możliwości oferty muzeum.

Na rysunku 2 zostały zestawione afordancje wizualne według trzech kluczowych źródeł charakterystyki oraz przykłady realizacji owych afordancji w MPW.

Komunikaty wizualne w przestrzeni muzeum mają swoje afordancje, to znaczy możliwości oddziaływania na odbiorców wynikające z trzech źródeł charakterystyki obrazów: semiotycznych, kognitywnych i kulturowych. Tym samym możemy syntetyzować rozległe pola znaczeniowe składające się na opis wielowymiarowych funkcji ikonosfery stwarzającej wyjątkowe doświadczenie z bycia w muzeum. Funkcje afordancji mogą uporządkować wizualne czynniki wpływu na indywidualny odbiór i społeczne interakcje publiczności instytucji kultury. Obrazy zapewniają stosunkowo dużą dowolność interpretacji, infiltrują widza, sprawiają, że ma wrażenie, iż sam poszerza „naturalnie” swoje pole interpretacji dla tego, na co patrzy. Sam na sam z ekranem w kinie muzeum ogląda film z historią polskiej wódki, gdzie PRL jest niczym z eleganckiej „korporacyjnej” prezentacji produktu. Lokowanie odbiorcy poprzez design przestrzeni muzeum (sale wystawowe, piętra oddzielne dla ekspozycji i jasny bar na końcu „podróży” przez instytucję) to kolejny etap wciągania odbiorcy w zaprojektowany świat znaczeń. Stworzenie średniowiecznej mapy $\mathrm{z}$ historią przybycia wódki na ziemie polskie czy drewnianego stołu otoczonego reprodukcjami malarskimi z wizerunkami dworów szlacheckich i zajazdów mają 
Afordancja - infiltracja (ang. infiltrate)

duża dowolność

interpretacji

Afordancja - lokowanie

porzez kompozycję

przestrzeni

(ang. spacialize)

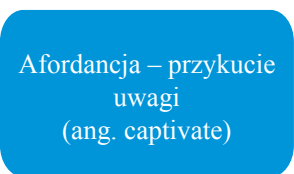

Afordancja -

materializacja

(ang. materialize)

\section{KULTUROWE I KOGNITYWNE UWARUNKOWANIA}

- Słabsze uwarunkowania społeczne dla obrazów

- Polisemiczność odbioru - łatwiejsze niż w tekście poszerzenie pola interpretacji

- W MPW można pokazać „,kulturalną wódkę” wykluczając obrazy alkoholizmu i patologii

\section{SEMIOTYCZNE UWARUNKOWANIA}

Konfiguracja głębi i odległości użyteczna wizualnie do pokazania wielowymiarowości zjawiska

- W czasie projekcji filmu włączyć znaki identyfikujące ,wódkę vintage", a mapą pokazać historię przybycia wódki do Polski
SEMIOTYCZNE I KOGNITYWNE UWARUNKOWANIA

- Obraz recypowany szybko i natychmiastowo, często poza refleksyjnym, pogłebionym przetwarzaniem (ang. precedes active awareness, surpasses purely cognitive processing)

- Indywidualizacja i ucieleśnienie perspektywy

- MPW oferuje np. interaktywne wizualizacje procesu destylacji.

Trudne kwestie chemiczne i produkcyjne stają się animacją na ścianie.

\section{SEMIOTYCZNE UWARUNKOWANIA}

- „Obiektywność” i „faktyczność” obrazów gwarantowana przez indeksyjność i ikoniczność użytych znaków; Lokalizacja budynku muzeum w Centrum „Koneser”.

- W MPW widać budynek z cegły ,jak dawniej”, oryginalne butelki ilustrują ,prawdę” przekazu instytucji

Rysunek 2. Afordancje przekazów wizualnych w MPW.

Źródło: opracowanie własne na podstawie modelu Meyer i współpracowników (2018).

aktywować zmysły odwiedzającego i dawać wrażenie bycia zanurzonym w historii. Obrazy recypowane są natychmiastowo, w tle towarzyszy im oczywiście werbalna opowieść przewodnika, ale najskuteczniej przykuwają uwagę migające płomienie nad alembikiem $\mathrm{z}$ wódką, animacje na ścianie czy ruchome wizualizacje rzucane projektorem na podłogę. A wszystko to według afordancji oferującej materializację jest „oczywiste”, „bezstronne”, „widocznie prawdziwe”. Można „dotknąć” historii wódki poprzez jej „faktyczne” reprezentacje, epistemologiczną „obiektywizację” w zaprojektowanej przecież przestrzeni muzeum organizacji realizującej swą strategię komunikacyjną. Teoria afordancji Gibsona miała za zadanie opisywać świat z perspektywy ekologicznej, środowiskowej, dostarczyć aparat teoretyczny do opisu środowiska, w którym organizmy pozostają $\mathrm{w}$ relacji $\mathrm{z}$ innymi organizmami oraz z przedmiotami nieożywionymi, także artefaktami kultury. Jeśli zastosować ją w mikroskali świata organizacji, jak w niniejszym opracowaniu (dodajmy, jak radzą także autorzy najnowszego podręcznika dotyczącego metodologii komunikacji wizualnej Doing Visual Analysis: From Theory to Practice, Per Ledin i David Machin 
[2018]), można skategoryzować możliwości wpływu wizualnej oferty instytucji. Ledin i Machin [2018: 18-25] podają analizę afordancji jako alternatywę dla analizy dyskursu czy praktyk stricte semiotycznych. Afordancje wynikające z intencjonalnie wytworzonych przekazów tworzą otoczenie bogate w znaczenia, angażujące, dające wybór w interpretacjach i zachowaniu, predestynowany jednak w ramach owych afordancji właśnie. To piktorialne informacje budowane w ramach trzech źródeł „infrastruktury” wizualnych komunikatów. To „oferty” [Klawiter 2012: 265], z których użytek robi „perceptor”, czyli gość instytucji kultury, który widzi na przykład animację produkcji okowity w przestrzeni organizacji. Kluczem jest to, że ma wybór, gdzie patrzy, ale już nie, na co patrzy.

\section{Podsumowanie}

„Badanie organizacji i jej wizualności skupia się na tym, jak znaczenie jest kreowane, komunikowane i przechowywane poprzez znaki wizualne" [Boxenbaum et al. 2018: 602]. Analizowanym wycinkiem rzeczywistości organizacji są komunikaty wizualne, a ich opis ma prowadzić do rozpoznania dynamiki i subiektywnego opisu funkcjonowania organizacji, zwłaszcza zaś jej praktyk komunikacyjnych i wizerunkowych. Przy przyjęciu metodologii konstruktywizmu społecznego, jak piszą Andrzej K. Koźmiński i Dominika Latusek-Jurczak, badacz

jest więc swego rodzaju tłumaczem znaczeń, łączącym własne doświadczenie z doświadczeniem członków organizacji (...). Sukcesem jest więc przebycie drogi od subiektywizmu do intersubiektywizmu, czyli zdolność rozszyfrowania wspólnych interpretacji rzeczywistości charakterystycznych dla określonych grup ludzkich w konkretnym czasie i uwarunkowaniach [Koźmiński, Latusek-Jurczak 2013: 31].

Szeregowanie owych interpretacji w niniejszym opracowaniu przebiegało według klucza czterech funkcji afordancji przekazów wizualnych w przestrzeni Muzeum Polskiej Wódki. Wyjaśniono źródła owych afordancji odwołując się do „infrastruktury" wizualnej komunikacji: semiotycznej, kognitywnej i kulturowej według modelu Meyer i zespołu [2018]. Podano przykłady do każdej z afordancji zaobserwowane $\mathrm{w}$ przestrzeni muzeum. Ramę do interpretacji stanowiły wywiady z przedstawicielami organizacji: na szczeblu pracownika oraz zarządzającego komunikacją, przeprowadzone niedługo po otwarciu placówki. Wywiady ujawniły spójną misję komunikowanych założeń, wskazały cele ekspozycji, a także definiowały strategię komunikacji MPW. Warto badanie przeprowadzić ponownie, zastosować strategię longitudinalną, aby uchwycić dynamikę zmian. Choć z racji nietradycyjnego wykorzystania modeli komunikacji wizualnej do analizy komunikacyjnych praktyk organizacji można wpisać pracę w nurt badań zorientowanych eksploracyjnie, to 
jednak ma on także swoją wartość aplikacyjną. Może stanowić praktyczną podbudowę dla specjalistów zarządzania i PR, zainteresowanych świadomym użyciem komunikatów wizualnych w swojej pracy. Tak rozumiane afordancje mogą być komplementarnym konstruktem teoriopoznawczym do opisu założeń strategii komunikacji wizualnej, a następnie mogą być wykorzystywane przez zarządzających instytucją kultury do jej wdrażania i wreszcie badania jej efektów. Propozycją metodologiczną byłoby konstruowanie narzędzia do badania publiczności według klucza funkcji afordancji z przypisanymi im najważniejszymi obiektami w muzeum. Zaprezentowane opracowanie to interdyscyplinarna próba opisu specyfiki instytucji kultury od strony społecznie konstruowanego świata obrazów oraz propozycja modelu afordancji do ich uchwycenia.

\section{Biblioggrafia}

Bańdo M., Król P., Parzyńska I., Szostak A. (2019), Charakterystyka typów instytucji kultury, [w:] Raport z projektu badawczego „Krakowski odbiorca kultury”, seria „Biblioteka Zarządzania Kulturą", t. 22, Kraków: Wydawnictwo Attyka, s. 103-199.

Berger J. (2008), Sposoby widzenia. Na podstawie cyklu programów telewizyjnych BBC Johna Bergera, tłum. M. Bryl, Warszawa: Fundacja Aletheia, s. 9-10.

Boxenbaum E., Jones C., Meyer R.E., Svejenova S. (2018), Towards an Articulation of the Material and Visual Turn in Organization Studies, „Organization Studies”, Vol. 39 (5-6), s. 597-616.

Carù A., Ostillio M.C., Leone G. (2017), Corporate Museums to Enhance Brand Authenticity in Luxury Goods Companies: The Case of Salvatore Ferragamo, „International Journal of Arts Management", Vol. 19 (2), s. 32-45.

Chmielecki K. (2018), Widzenie przez kulturę. Wprowadzenie do teorii kultury wizualnej, Gdańsk: Katedra Wydawnictwo Naukowe.

Corenlissen J. (2010), Komunikacja korporacyjna. Przewodnik po teorii i praktyce, tłum. J. Kuczyński, Warszawa: Wolters Kluwer Polska.

Czarniawska B. (2013), Trochę inna teoria organizacji, Warszawa: Poltext.

Datko A., Necel R. (2011), Nowoczesna instytucja kultury. Raport z badań, Poznań: Uniwersytet im. Adama Mickiewicza, Instytut Socjologii.

Dragićević Šešić M., Stojković B. (2010), Kultura. Zarzadzanie, animacja, marketing, tłum. J. Ambroziak, Warszawa: Narodowe Centrum Kultury.

Dzidowski A. (2011), Antropologia wizualna organizacji, „Problemy Zarządzania”, Vol. 9, No. 2 (32), s. 51-62.

Dziewianowska K., Kacprzak A. (2013), Marketing doświadczeń, Warszawa: Wydawnictwo Naukowe PWN.

Gibson J.J. (1966), The Senses Considered as Perceptual Systems, Boston: Houghton Mifflin Harcourt.

Hudzik J.P. (2017), Wykłady z filozofii mediów. Podstawy nauk o komunikowaniu, Warszawa: Wydawnictwo Naukowe PWN. 
Iannone F., Izzo F. (2017), Salvatore Ferragamo: An Italian Heritage Brand and Its Museum, „Place Branding and Public Diplomacy”, Vol. 13, Iss. 2, s. 163-175.

Imbir K., Jarymowicz M. (2011), Wzbudzanie emocji o genezie automatycznej badź refleksyjnej a przejawy poznawczej kontroli w Emocjonalnym Teście Stroopa, „Psychologia - Etologia Genetyka", 24, s. 7-25.

Kaczmarek-Sliwińska M. (2015), Muzeum firmowe jako forma komunikowania się marek $z$ otoczeniem, [w:] M. Kaczmarek-Śliwińska, Organizacje i idee - komunikowanie się w przestrzeni tradycyjnych i nowych mediów, Koszalin: Wydawnictwo Uczelniane Politechniki Koszalińskiej.

Klawiter A. (2012), What Will You Do to Me When You See Me? Perception As Searching for Affordances in the Environment [Co ze mną zrobisz, kiedy mnie zobaczysz? Percepcja jako wyszukiwanie ofert (affordances) w otoczeniu], „Avant. Pismo Awangardy Filozoficzno-Naukowej", t. 3, nr 2, s. 261-266.

Kożuch B. (2007), Nauka o organizacji, Warszawa: CeDeWu.

Koźmiński A.K., Latusek-Jurczak D. (2011), Rozwój teorii organizacji, Warszawa: Wolters Kluwer Polska.

Kress G., Leeuwen T. van (2006), Reading Images: The Grammar of Visual Design, $2^{\text {nd }}$ ed., London: Routledge.

Ledin P., Machin D. (2018), Doing Visual Analysis: From Theory to Practice, London: Sage.

Maćkiewicz J. (2017), Badanie mediów multimodalnych - multimodalne badanie mediów, „Studia Medioznawcze", t. 2, nr 69, s. 33-42.

Meyer R.E., Jancsary D., Höllerer M.A., Boxenbaum E. (2018), The Role of Verbal and Visual Text in the Process of Institutionalization, „Academy of Management Review”, Vol. 43, Iss. 3, s. 392-418.

Mirzoeff N. (2016), Jak zobaczyć świat, tłum. Ł. Zaremba, Kraków: Wydawnictwo Karakter, Warszawa: Muzeum Sztuki Nowoczesnej.

Młodkowski J. (1998), Aktywność wizualna człowieka, Warszawa-Łódź: Wydawnictwo Naukowe PWN.

Newton H.J. (2004), Visual Ethics Theory, [w:] K.I. Smith (red.), Handbook of Visual Communication: Theory, Methods and Media, New York: „Lawrence Erlbaum”, s. 429-443.

Pabian A., Pabian A. (2009), Muzea firmowe jako nowoczesne narzędzie public relations, [w:] R. Maćkowska, H. Przybylski (red.), Public relations. Aktualne zagadnienia sztuki komunikowania w teorii i praktyce, Katowice: Wydawnictwo Akademii Ekonomicznej im. Karola Adamieckiego w Katowicach.

Paplińska M. (2008), Niepetnosprawność wzroku i jej psychospołeczna specyfika, [w:] M. Czerwińska (red.), Niewidomi w kulturze - od terapii do sztuki. Wybrane zagadnienia, „Przegląd Tyflologiczny", nr 1-2 (38-39), s. 12-28.

Pokojska W. (2014), Mercedes-Benz Museum Stuttgart - muzeum idealne? „Zarządzanie w Kulturze", t. 15, nr 2, s. 117-130.

Rose G. (2010), Interpretacja materiałów wizualnych. Krytyczna metodologia badań nad wizualnościa, tłum. E. Klekot, Warszawa: Wydawnictwo Naukowe PWN. 
Shaw C. (2005), Revolutionize Your Customer Experience, New York: Palgrave Macmillan.

Smit B. (2014), The Heineken Story: The Remarkably Refreshing Tale of the Beer That Conquered the World, London: Profile Books.

Strumińska-Kutra M., Koładkiewicz I., Studium przypadku, [w:] D. Jemielniak (red.), Badania jakościowe, t. 2: Metody i narzędzia, Warszawa: Wydawnictwo Naukowe PWN, s. 1-37.

Szlendak T., Nowiński J., Wieczorek P. (2012), Podręcznik szkoleniowy dotyczący sektora kultury w Polsce dla wnioskodawców i partnerów Programu „Promowanie różnorodności kulturowej $i$ artystycznej w ramach europejskiego dziedzictwa kulturowego" finansowanego $z$ funduszy EOG 2009-2014, Warszawa: Ministerstwo Kultury i Dziedzictwa Narodowego.

Szulborska-Łukaszewicz (2012), Instytucja kultury w Polsce - specyfika ich organizacji i zarzadzania, „Zarządzanie w Kulturze”, t. 13, nr 4, s. 305-328.

Szwajca D. (2009), Pozycjonowanie marki na rynku globalnym - możliwości i ograniczenia, „Economy and Management”, t. 1, s. 44-59.

\section{Netografia}

Raport GUS (2017), Działalność muzeów w 2017 roku, https://stat.gov.pl/files/gfx/portalinformacyjny/pl/defaultaktualnosci/5493/20/1/1/dzialalnosc_muzeow_w_2017_r.pdf [odczyt: 10.04.2019].

Raport MKiDN (2007), Finansowanie kultury i zarządzanie instytucjami kultury, https://nck. pl/upload/attachments/302373/finansowanie_kultury_copy2.pdf [odczyt: 10.04.2019].

Sprawozdanie Fundacji Polska Wódka (2018), http://fundacjapolskawodka.org/\# [odczyt: 10.04.2019]. 